\title{
Treating cytomegalovirus infection among infantile cholestasis: a single centre experience
}

\author{
Karthik Ram Mohan ${ }^{1}$, *A K Simalti ${ }^{2}$, Randhir Ranjan ${ }^{3}$
}

Sri Lanka Journal of Child Health, 2021; 50(2): 312-317

\begin{abstract}
Background: Studies have suggested that various viral infections are associated with intra-hepatic forms of infantile cholestasis. Cytomegalovirus (CMV) is most commonly implicated among infective causes of neonatal cholestasis. We present our experience in a referral centre where we detected 6 cases of CMV infection among infants presenting with cholestasis.
\end{abstract}

Objectives: To assess the prevalence of CMV infection among infants presenting with cholestasis and the feasibility of antiviral treatment while monitoring for side effects and viral shedding in urine.

Method: In a prospective descriptive study, 19 infants with infantile cholestasis were admitted. They all were evaluated as per Indian Academy of Paediatrics (IAP) consensus for neonatal cholestasis. Urine testing for CMV viral PCR (quantitative) was done in all children.

Results: The median age at presentation was 3 months (range 3 weeks - 11 months). Out of 19 children with cholestasis, $6(31.6 \%)$ were positive for urine CMV PCR and were included in this study. Ongoing CMV infection was defined by quantifying copy numbers in urine CMV PCR. These infants were given intravenous ganciclovir, followed by oral valganciclovir for 6 months or till urine CMV PCR remained positive whichever was later. At end of our study, four patients had good outcome, one intermediate and one infant died. All but one infant responded virologically. None of the

${ }^{1}$ Senior Advisor, Department of Paediatrics and Neonatology, Command Hospital, Kolkata, India, ${ }^{2}$ Paediatric Intensivist, ${ }^{3}$ Junior Resident, Army Hospital (Research \& Referral), New Delhi, India, *Correspondence: ashishsimalti@rediffmail.com

(iD), https://orcid.org/0000-0002-8227-9038

(Received on 13 June 2020: Accepted after revision on 24 July 2020)

The authors declare that there are no conflicts of interest

Personal funding was used for the project.

Open Access Article published under the Creative Commons Attribution CC-BY (c) (i) License patients required withdrawal of ganciclovir or valganciclovir because of adverse effects.

Conclusions: Out of 19 children with cholestasis, 6 $(31.6 \%)$ were positive for urine CMV PCR. Four patients had good outcome to antiviral therapy.

DOI: http://dx.doi.org/10.4038/sljch.v50i2.9602

(Key words: CMV, infantile cholestasis, ganciclovir)

\section{Introduction}

Incidence of cholestatic jaundice among term infants has been estimated to be around 1 in every 2500 term infants with biliary atresia (BA) being the commonest aetiology ${ }^{1}$. Its incidence ranges from $25 \%$ to $40 \%$ in various case series ${ }^{2}$. A second group belongs to an array of genetic disorders $(25 \%)$ which individually are uncommon ${ }^{2}$. The third common group is labelled as idiopathic neonatal hepatitis, the incidence of which is declining with advances in diagnostic evaluation. One such example is the use of polymerase chain reaction (PCR) for detection of viral infection. Studies have suggested that various viral infections are associated with intra-hepatic forms of infantile cholestasis $^{3}$. Cytomegalovirus (CMV) is most commonly implicated among infective causes of neonatal cholestasis ${ }^{4}$. Fischler $\mathrm{B}$, et $a l^{5}$ demonstrated a possible association between CMV infection and BA. With wider availability of viral PCR we are picking up these infections more frequently than before. We present our experience in a referral centre where we detected 6 cases of $\mathrm{CMV}$ infection among infants presenting with cholestasis.

\section{Objectives}

To assess the prevalence of CMV infection among infants presenting with cholestasis and the feasibility of antiviral treatment while monitoring for side effects and viral shedding in urine.

\section{Method}

In a prospective descriptive study, from January 2017 to December 2019, 19 infants with cholestasis were admitted at our institute, a tertiary care referral paediatric centre in New Delhi, India. They all were evaluated as per Indian Academy of Paediatrics (IAP) consensus for neonatal 
cholestasis $^{6}$. As part of the work-up, urine testing for CMV viral PCR (Quantitative) was done for all children. As a protocol of our institute, these infants were given intravenous (IV) Ganciclovir, $6 \mathrm{mg} / \mathrm{kg} /$ dose twice daily for 2 weeks, followed by oral Valganciclovir $16 \mathrm{mg} / \mathrm{kg} /$ dose twice daily for 6 months or till urine CMV PCR remained positive whichever was later.

Ethical issues: Ethical clearance was obtained from the Institutional Ethics Committee of Army Hospital (Research \& Referral), New Delhi, India (IEC No. 869 /2018). Written informed parental consent was obtained from the parents of the participants.

\section{Results}

The median age at presentation was 3 months (range 3 weeks -11 months). Out of 19 children with cholestasis, $6(31.6 \%)$ were positive for urine CMV PCR and were included in this study. Demographic profiles of these 6 infants with cholestasis and CMV infection at admission are summarized in Table 1.

Table 1: Demographic profile of study population

\begin{tabular}{|c|c|c|c|c|c|c|}
\hline $\begin{array}{c}\text { Serial } \\
\text { No. }\end{array}$ & $\begin{array}{c}\text { Age at } \\
\text { presentation to } \\
\text { referral hospital }\end{array}$ & Sex & $\begin{array}{c}\text { Age when } \\
\text { Jaundice noticed } \\
\text { by parents }\end{array}$ & $\begin{array}{c}\text { Stool } \\
\text { colour }\end{array}$ & $\begin{array}{c}\text { Other symptoms/signs } \\
\text { at onset }\end{array}$ & Final diagnosis \\
\hline 1 & 5 months & $\mathrm{M}$ & 3 months & Pale & None & Biliary atresia \\
\hline 2 & 3 months & $\mathrm{M}$ & 3 months & Pale & Failure to thrive & $\begin{array}{c}\text { Idiopathic neonatal } \\
\text { hepatitis }\end{array}$ \\
\hline 3 & 4 months & $\mathrm{F}$ & 4 months & Yellow & None & Biliary atresia \\
\hline 4 & 3 months & $\mathrm{M}$ & $2 \frac{1}{2}$ months & Yellow & Failure to thrive & Biliary atresia \\
\hline 5 & 3 weeks & $\mathrm{F}$ & 3 weeks & Yellow & $\begin{array}{c}\text { Respiratory distress, } \\
\text { failure to thrive }\end{array}$ & $\begin{array}{c}\text { Congenital CMV } \\
\text { infection }\end{array}$ \\
\hline 6 & 4 months & $\mathrm{M}$ & 3 months & Yellow & None & $\begin{array}{c}\text { Dubin Johnson } \\
\text { syndrome }\end{array}$ \\
\hline
\end{tabular}

All were younger than 5 months of age. Ongoing CMV infection was defined by quantifying copy numbers in urine CMV PCR. Out of these 6 patients, 3 had biliary atresia (Patient serial numbers 1, 3 and 4), one had splenomegaly with pneumonia, besides cholestasis giving rise to suspicion of congenital infection (Patient serial number 5) and two had clinical intrahepatic cholestasis but no specific metabolic or other infectious cause could be detected on evaluation (Patient serial numbers 2 and 6). One infant was later diagnosed as Dubin Johnson syndrome based on genetic analysis when baby continued to remain well but was mildly icteric even after 6 months of follow up (Patient serial number 6). Liver biopsy findings were suggestive of biliary atresia in 3 patients (Patient serial numbers 1,3 and 4) and showed signs of giant-cell hepatitis in 2 patients (Patient serial numbers 2 and 5). In none of the cases could CMV inclusions be seen. Immunohistochemistry or in situ hybridization for CMV could not be performed. In patient serial number 5, there was a history of prematurity, intrauterine growth retardation and respiratory distress suggesting the possibility of congenital infection. This neonate was 3 weeks old at the time of evaluation. In other babies CMV infection was diagnosed after 3 weeks of age and it is not easy to differentiate whether CMV infection was acquired antenatally or postnatally (Table 1). Mothers were also evaluated for the same in all 6 cases. None of the mothers had any antenatal evaluation done for CMV. Serum IgM antibodies against CMV were not found in any mother thus ruling out recent infection but all were positive for CMV IgG.

These infants were given intravenous (IV) Ganciclovir, $6 \mathrm{mg} / \mathrm{kg} /$ dose twice daily for 2 weeks, followed by oral Valganciclovir $16 \mathrm{mg} / \mathrm{kg} / \mathrm{dose}$ twice daily for 6 months or till urine CMV PCR remained positive whichever was later. All patients were started on supplementation with fat-soluble and water soluble vitamins in recommended dosing and ursodeoxycholic acid (UDCA) for symptomatic management of cholestasis. Bone marrow depression is the most dreaded adverse effect of these antiviral agents and hence, these infants were monitored initially weekly for first 4 weeks and later monthly by performing complete blood count and peripheral blood smear which was normal in all.

These babies were followed up for 12 months on an outpatient basis after discharge and follow up included clinical evaluation, stool colour examination, serum levels of conjugated bilirubin, SGOT, SGPT, serum albumin levels and prothrombin time. Urine for CMV- PCR was done 3 monthly till documented negative twice. The clinical outcome was considered good when liver disease was mild, intermediate if liver disease was chronic compensated and poor if the patient died or needed liver transplantation. At end of our study, four patients had good outcome, one intermediate and one infant died (Table 2). 
Table 2: Outcome details

\begin{tabular}{|c|c|c|c|c|c|c|c|c|c|c|}
\hline \multirow[t]{2}{*}{$\begin{array}{c}\text { Serial } \\
\text { No. }\end{array}$} & \multirow[t]{2}{*}{$\begin{array}{l}\text { Duration of } \\
\text { follow up } \\
\text { (months) }\end{array}$} & \multicolumn{2}{|c|}{$\begin{array}{l}\text { S Bilirubin } \\
\text { (mg/100ml) }\end{array}$} & \multicolumn{2}{|c|}{$\begin{array}{l}\text { SGPT } \\
\text { (U/L) }\end{array}$} & \multicolumn{2}{|c|}{ INR } & \multicolumn{2}{|c|}{$\begin{array}{c}\text { Urine CMV PCR for copy } \\
\text { number } \\
\text { (IU/ml) }\end{array}$} & \multirow[t]{2}{*}{ Outcome } \\
\hline & & $\begin{array}{l}\text { At } \\
\text { admission }\end{array}$ & $\begin{array}{l}\text { At end of } \\
\text { follow up }\end{array}$ & $\begin{array}{l}\text { At } \\
\text { admission }\end{array}$ & $\begin{array}{l}\text { At end of } \\
\text { follow up }\end{array}$ & $\begin{array}{l}\text { At } \\
\text { admission }\end{array}$ & $\begin{array}{l}\text { At end of } \\
\text { follow up }\end{array}$ & $\begin{array}{l}\text { At } \\
\text { admission }\end{array}$ & $\begin{array}{l}\text { At end of } \\
\text { follow up }\end{array}$ & \\
\hline 1 & 12 & 3 & 2 & 70 & 40 & 2 & 1.3 & 285,000 & ND & Intermediate \\
\hline 2 & 9 & 9 & 1 & 90 & 50 & 1.5 & 1.4 & 33,000 & ND & Good \\
\hline 3 & 12 & 5 & 1.2 & 80 & 40 & 1.6 & 1.3 & 21,000 & ND & Good \\
\hline 4 & 6 & 4 & 16 & 40 & 100 & 2 & 6 & 1,900 & ND & Poor \\
\hline 5 & 12 & 5 & 1 & 60 & 40 & 1.5 & 1.2 & 217,350 & 1,700 & Good \\
\hline 6 & 12 & 6 & 4 & 60 & 40 & 1.2 & 1.3 & 25,000 & ND & Good \\
\hline
\end{tabular}

All but one infant (Serial number 5) responded virologically. In patient serial number 5 , initially there was drop in viral copy number from a million to a hundred but again it rose to a thousand. After discussion with the virologist, leucocyte DNA assessment was done at 12 months of age which did not reveal infection and Valganciclovir was stopped. Liver failure developed in one of the infants with biliary atresia (Serial number 4) a few weeks after surgical procedure (Kasai), and he died of fulminant liver failure while awaiting liver transplantation at the age of 6 months. Patient serial number 6 with Dubin Johnson syndrome remained asymptomatic and parents were counselled about the disease and treatment was stopped. None of the patients required withdrawal of Ganciclovir or Valganciclovir because of adverse effects.

\section{Discussion}

CMV infection is of a ubiquitous nature and this makes it difficult to establish evidence of the causative role of CMV in infantile cholestasis even when presence of infection is confirmed. If virus is isolated within 2-3 weeks after birth, it can be assumed to be congenital in nature ${ }^{7}$. If CMV is detected after the age of 3 weeks, diagnosis of congenital infection needs support of clinical and epidemiologic features ${ }^{8,9}$. The prevalence of CMV in infantile cholestasis in various studies range from as low as $5 \%$ even up to $46 \%{ }^{10,11,12}$. The reported incidence also depends on the diagnostic method used. Bellomo-Brandao MA, et $a l^{13}$ compared different methods namely serology, histological revision, immunohistochemistry and PCR in the same population to get very different results.

In our study we found CMV positivity based on urine PCR to be 6 among 19 infants (31.6\%) which is much higher than $8 \%$ reported by BellomoBrandao MA, et $a l^{13}$ using the same technique. Chang MA, et $a l^{11}$ have reported incidence to be $26 \%$ in their group of 50 infants. Shibata $\mathrm{Y}$, et al ${ }^{14}$ reported $15.4 \%$ incidence while studying age group up to 24 months but their entry criteria were raised liver enzymes and not cholestasis. Even when CMV has been found it is not clear if it is the causative agent, or an aggravator of the cholestatic process, or even an "innocent bystander"15. This presents a dilemma as to when antiviral treatment should be initiated. In our study, a patient, who was finally diagnosed as Dubin Johnson syndrome, clearly did not need to be treated with antiviral agents while the neonate who was positive within 3 weeks of age, and had pneumonia too, definitely benefited from this treatment. In cases diagnosed as biliary atresia (BA), there is evidence that CMV infection may be aggravating the cholestasis and treatment may be beneficial ${ }^{16}$. It is not yet clear if CMV infection leads to $\mathrm{BA}^{17}$. It has been proposed that cytopathic effect of active CMV replication in hepatocytes and cholangiocytes as well as the potentially harmful immune response of the host may be responsible for BA in some cases ${ }^{18}$.

Chang MA, et al ${ }^{11}$ have suggested that CMV could be causative of neonatal hepatitis in a study involving 50 infants with cholestasis with $46 \%$ being positive for CMV. Fischler, et $a l^{3}$ have suggested that CMV may trigger an immunological process ultimately leading to BA based on significantly higher IgM deposits on liver biopsies done for BA. There is still no clear consensus regarding treatment of $\mathrm{CMV}$ in infants with $\mathrm{BA}$. Some studies recommend antiviral treatment if evidence of hepatitis or proven histopathological findings are present ${ }^{19,20}$ while others suggest antiviral treatment for all infant with BA who have evidence of $\mathrm{CMV}$ infection ${ }^{21}$. In our study there were 3 infants with BA and CMV infection, out of whom, one had good outcome post-surgery, one had compensated chronic liver disease post-Kasai procedure, while one died. While this may be too small a number to draw any conclusions, given the overall poor prognosis of these cases, in a setup where liver transplantation is not easily available, looking for and treating CMV may be considered an option.

Besides managing CMV for cholestasis one must be aware of other manifestations of CMV infection and some studies have shown that the CMV DNAPCR positivity impacts neurological outcome even if infant is asymptomatic at birth ${ }^{22,23}$. High viral load in early infancy has been shown to be predictive of audiological impairment ${ }^{24,25}$. In view of these findings it seems rational to treat all the infants who have been found to be infected with CMV.

There are four antiviral agents which are licensed to be used against CMV infection namely 
ganciclovir, valganciclovir, foscarnet and cidofovir; the latter 2 are not used in congenital CMV infection. Ganciclovir was first used for congenital CMV infection in late $1980 \mathrm{~s}^{26}$ and since then it has been shown to be well-tolerated and generally safe for neonates and infants. Valganciclovir, a pro drug of Ganciclovir is more convenient for long term use because of good oral bioavailability. The therapeutic regimens are still evolving and some researchers prefer using Valganciclovir from beginning while some recommend IV Ganciclovir in presence of organ damage and reserve oral treatment for asymptomatic infants ${ }^{27}$. Similarly there is no consensus on optimal duration of treatment with some studies recommending 6 weeks while some suggest longer even up to 1 year $^{28}$. In our study, we followed 6 months duration as per standard recommendations ${ }^{29}$.

\section{Conclusions}

In our study, out of 19 children with cholestasis, 6 (31.6\%) were positive for urine CMV PCR. Four patients had good outcome with antiviral therapy.

\section{References}

1. Dick MC, Mowat AP. Hepatitis syndrome in infancy-an epidemiological survey with 10 year follow up. Archives of Disease in Childhood 1985; 60:512-6. https://doi.org/10.1136/adc.60.6.512 PMid: 3874604 PMCid: PMC1777358

2. Fawaz R, Baumann U, Ekong U, Fischler B, Hadzic N, Mack CL, et al. Guideline for the evaluation of cholestatic jaundice in infants: joint recommendations of the North American Society for Pediatric Gastroenterology, Hepatology, and Nutrition and the European Society for Pediatric Gastroenterology, Hepatology, and Nutrition. Journal of Pediatric Gastroenterology and Nutrition 2017; 64(1): 154-68.

https://doi.org/10.1097/MPG.0000000000 001334

PMid: 27429428

3. Plosa EJ, Esbenshade JC, Fuller MP, Weitkamp JH. Cytomegalovirus infection. Pediatrics in Review 2012; 33(4):156-63. https://doi.org/10.1542/pir.33-4-156

PMid: 22474112

4. Kage M, Kosai K, Kojiro M, Nakamura Y, Fukuda S. Infantile cholestasis due to cytomegalovirus infection of the liver. A possible cause of paucity of interlobular bile ducts. Archives of Pathology and Laboratory Medicine 1993; 117:942-4.

5. Fischler B, Ehrnst A, Forsgren M, Orvell $\mathrm{C}$, Nemeth $\mathrm{A}$. The viral association of neonatal cholestasis in Sweden, a possible link between cytomegalovirus and extrahepatic biliary atresia. Journal of Pediatric Gastroenterology and Nutrition 1998; 27:57-64.

https://doi.org/10.1097/000051761998070 00-00010

PMid: 9669727

6. Bhatia V, Bavdekar A, Matthai J, Waikar Y, Sibal A. Management of neonatal cholestasis: Consensus Statement of the Pediatric Gastroenterology Chapter of Indian Academy of Pediatrics. Indian Pediatrics 2014; 51(3): 203-10. https://doi.org/10.1007/s13312-014-03752

PMid: 24736908

7. Stagno S, Pass RF, Dworsky ME, Alford CA. Congenital and perinatal cytomegalovirus infections. Seminars in Perinatology 1983; 7:31-42.

8. De Tommaso AM, Andrade PD, Costa SC, Escanhoela CA, Hessel G. High frequency of human cytomegalovirus DNA in the liver of infants with extrahepatic neonatal cholestasis. $B M C$ Infectious Diseases 2005; 5(1):108. https://doi.org/10.1186/1471-2334-5-108 PMid: 16321152 PMCid: PMC1315325

9. Wieringa JW, de Vries JJ, Murk JL. Congenital CMV infections. Ned Tijdschr Geneeskd 2013; 157(41): A6250.

10. Yamamoto AY, Figueiredo LT, MussiPinhata MM. Prevalence and clinical aspects of congenital cytomegalovirus infection. Journal of Pediatrics (Rio J) 1999; 75: 23-8.

https://doi.org/10.2223/JPED.252

PMid: 14685559

11. Chang MH, Huang HH, Huang ES, Kao CL, Hsu HY, Lee CY. Polymerase chain reaction to detect human cytomegalovirus in livers of infants with neonatal hepatitis. Gastroenterology 1992; 103: 1022-5. https://doi.org/10.1016/00165085(92)9003 $8-\mathrm{Z}$

12. Fischler B, Rodensjö $\mathrm{P}$, Nemeth A, Forsgren M, Lewensohn-Fuchs I. 
Cytomegalovirus DNA detection on Guthrie cards in patients with neonatal cholestasis. Archives of Disease in Childhood Fetal and Neonatal Edition 1999; 80: F130-F134.

https://doi.org/10.1136/fn.80.2.F130

PMid: 10325791 PMCid: PMC1720908

13. Bellomo-Brandao MA, Andrade PD, Costa SC, Escanhoela CA, Vassallo J, Porta $\mathrm{G}$, et al. Cytomegalovirus frequency in neonatal intrahepatic cholestasis determined by serology, histology, immunohistochemistry and PCR. World Journal of Gastroenterology 2009; 15(27): 3411-6.

https://doi.org/10.3748/wjg.15.3411

PMid: 19610143 PMCid: PMC2712903

14. Shibata Y, Kitajima N, Kawada J, Sugaya $\mathrm{N}$, Nishikawa $\mathrm{K}$, Morishima $\mathrm{T}$, et al. Association of cytomegalovirus with infantile hepatitis. Microbiology and Immunology 2005; 49: 771-7.

https://doi.org/10.1111/j.13480421.2005.t b03667.x

PMid: 16113505

15. Persing DH, Rakela J. Polymerase chain reaction for the detection of hepatitis viruses: panacea or purgatory? Gastroenterology 1992; 103: 1098-9. https://doi.org/10.1016/00165085(92)9004 9-5

16. Zani A, Quaglia A, Hadzić N, Zuckerman M, Davenport M. Cytomegalovirusassociated biliary atresia: an aetiological and prognostic subgroup. Journal of Pediatric Surgery 2015; 50(10):1739-45. https://doi.org/10.1016/j.jpedsurg.2015.03 .001

PMid: 25824438

17. Fischler B, Wozenius S, Nemeth A, Papadogiannakis N. Immunoglobulin deposits in liver tissue from infants with biliary atresia and the correlation to cytomegalovirus infection. Journal of Pediatric Surgery 2005; 40:541-6. https://doi.org/10.1016/j.jpedsurg.2004.11 .035

PMid: 15793732

18. Ozkan TB, Mistik R, Dikici B, Nazlioglu HD. Antiviral therapy in neonatal cholestatic cytomegalovirus hepatitis. BMC Gastroenterology 2007; 7: 9. https://doi.org/10.1186/1471-230X-7-9 PMid: 17355631 PMCid: PMC1847446
19. Tezer H, Secmeer G, Kara A, Ceyhan M, Cengiz AB, Devrim I, et al. Cytomegalovirus hepatitis and ganciclovir treatment in immunocompetent children. Turkish Journal of Pediatrics 2008; 50:228-34.

20. Fischler B, Casswall TH, Malmborg P, Nemeth A. Ganciclovir treatment in infants with cytomegalovirus infection and cholestasis. Journal of Pediatric Gastroenterology and Nutrition 2002; 34: 154-7.

https://doi.org/10.1097/000051762002020 00-00009

PMid: 11840032

21. Shah I, Bhatnagar S. Biliary atresia and cytomegalovirus and response to valganciclovir. Indian Pediatrics 2012; 49: 484-6. https://doi.org/10.1007/s13312-012-00927

PMid: 22796690

22. Noyola DE, Demmler GI, Williamson WD, Griesser C, Sellers S, Llorente A, et al. Congenital CMV longitudinal study group. Cytomegalovirus urinary excretion and long-term outcome in children with congenital cytomegalovirus infection. Pediatric Infectious Disease Journal 2000; 19: 505-10.

https://doi.org/10.1097/000064542000060 00-00003

PMid: 10877163

23. Gandhi RS, Fernandez-Alvarez JR, RabeH. Management of congenital cytomegalovirus infection: an evidencebased approach. Acta Paediatrica 2010; Available from:

https://onlinelibrary.wiley.com/doi/pdf/10. 1111/j.1651-2227.2009.01655.x https://doi.org/10.1111/j.16512227.2009.0 1655.x

PMid: 20050828

24. Rivera LB, Boppana SB, Fowler KB, Britt WJ, StagnoS, Pass RF. Predictors of hearing loss in children with symptomatic congenital cytomegalovirus infection. Pediatrics 2002; 110: 762-7. https://doi.org/10.1542/peds.110.4.762 PMid: 12359792

25. Kylat RI, Kelly EN, Lee Ford-Jones E. Clinical findings and adverse outcome in 
neonates with symptomatic congenital cytomegalovirus (SCCMV) infection. European Journal of Pediatrics 2006; 165: $773-8$.

https://doi.org/10.1007/s00431-006-01726

PMid: 16835757

26. Hocker J, Cook LN, Adams G, Rabalais G. Ganciclovir therapy of congenital cytomegalovirus pneumonia. Pediatric Infectious Disease Journal 1990; 9: 743-5. https://doi.org/10.1097/000064541990100 00-00013

PMid: 2172904

27. Buonsenso D, Serranti D, Gargiullo L, Ceccarelli M, Ranno O, Valentini P. Congenital cytomegalovirus infection: current strategies and future perspectives. European Review for Medical and Pharmacological Sciences 2012; 16(7): 919-35.
28. Amir J, Wolf DG, Levy I. Treatment of symptomatic congenital cytomegalovirus infection with intravenous ganciclovir followed by long-term oral valganciclovir. European Journal of Pediatrics 2010; 169: 1061-7.

https://doi.org/10.1007/s00431-010-11769

PMid: 20232081

29. Britt WJ. Cytomegalovirus. In: Kliegman RM, Blum NJ, Shah SS, Gemer JW, Tasker RC, Wilson KM, Behrman RE, editors. Nelson textbook of Pediatrics. $21^{\text {th }}$ ed. Philadelphia: Elsevier, 2020. p. 171823 